\title{
Prevalence of color vision deficiency among school children in Wolkite, Southern Ethiopia
}

\author{
Gashaw Garedew Woldeamanuel ${ }^{*}$ and Teshome Gensa Geta
}

\begin{abstract}
Objective: Colour vision deficiency is the commonest disorders of vision and undiagnosed colour vision defect could pose a handicap to the performance of an affected student. The prevalence of colour blindness varies in different geographical area and ethnicity. Hence, a cross sectional study was conducted among school children in Gurage Zone, Southern Ethiopia from April 15 to June 20, 2018. Socio-demographic data was collected on a face to face interview using structured questionnaire. All study participants underwent color vision evaluation using Ishihara's pseudo isochromatic test 38 plate editions. Data analysis was done using SPSS version 23.

Results: A total of 844 (471 boys and 373 girls) school children were screened for colour vision. The overall prevalence of colour vision deficiency was $4.1 \%$, comprised of $3.6 \%$ in boys and $0.6 \%$ in girls. Out of 35 color blind subjects, $15(42.9 \%)$ and 20 (57.1\%) were the victims of protan and deutan defects respectively. Majority of the colour blind subjects were not aware of their colour vision status. Hence, the study concluded that the prevalence of colour vision deficiency in our study is significant and colour vision screening among school should be performed.
\end{abstract}

Keywords: Colour vision deficiency, Prevalence, School children

\section{Introduction}

Colour vision deficiency (CVD) or colour blindness, is the inability or decreased ability to distinguish different colours under normal lighting conditions [1]. It is one of the commonest disorders of vision [2] and the incidence of CVD varies from race to race and different in different geographical area [3, 4]. However, most of colour blind cases remain undetected due to absence of proper screening [5].

Colour vision deficiency may be congenital or acquired. Congenital colour defects are non pathologic, incurable, and constant throughout life [6]. It is the commonest $\mathrm{X}$ - linked recessive disorder and affects as many as $8 \%$ of males and $0.5 \%$ of females [2]. There are also different causes for acquired colour vision defects, such as ocular

*Correspondence: gashawgaredew05@gmail.com

Department of Biomedical Sciences, School of Medicine, College

of Medicine and Health Sciences, Wolkite University, P.O. Box 07, Wolkite,

Ethiopia or neurological disease, some metabolic disorders, drug toxicity and exposure to certain solvents $[5,7]$.

Alterations of the three (red, green and blue) cone pigments are responsible for colour vision deficiencies. The commonest form of deficient colour vision is red-green deficiency [8,9], in which either of the red or green cones is missing. The prevalence of red-green colour deficiency in European Caucasians is about $8 \%$ in men and about $0.4 \%$ in women and between $4 \%$ and $6.5 \%$ in men of Chinese and Japanese ethnicity. The prevalence is also rising in men of African ethnicity [10].

Colour vision deficiency does not cause complete blindness and there is no available therapeutics that can treat CVD [11]. However, colour vision is crucial to an individual's understanding of their visual world, and those with colour vision defects can experience difficulties in everyday life [5]. Those who have CVD will be better able to adapt and make more informed career choices, if they know about their colour vision status. However, a high proportion of school children are unaware of their colour vision status and undiagnosed CVD

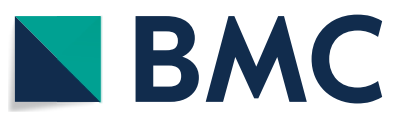

(c) The Author(s) 2018. This article is distributed under the terms of the Creative Commons Attribution 4.0 International License (http://creativecommons.org/licenses/by/4.0/), which permits unrestricted use, distribution, and reproduction in any medium, provided you give appropriate credit to the original author(s) and the source, provide a link to the Creative Commons license, and indicate if changes were made. The Creative Commons Public Domain Dedication waiver (http://creativecommons.org/ publicdomain/zero/1.0/) applies to the data made available in this article, unless otherwise stated. 
could pose a handicap to the scholarly performance of an affected student [12]. Moreover, early detection of colour vision malfunction in children allows parents and teachers to make necessary adjustments to the teaching methods for appropriate learning [13]. There is only limited report in Ethiopia and no such report in the southern Ethiopia about the prevalence of colour blindness among both sexes of school children. Hence, the aim of this study was to determine the prevalence of colour vision deficiency among school children in Wolkite town, Southern Ethiopia.

\section{Main text \\ Methods and materials \\ Study area and sampling}

School based cross sectional study was conducted in Wolkite town, Southern Ethiopia from April 15 to June 20, 2018. Wolkite town is located at about $158 \mathrm{~km}$ from the capital city, Addis Ababa. In the year 2018, the town had a total of 12 primary schools hosting approximately 13,510 (6820 boys and 6690 girls) students from grade $1-8$.

The source populations of the study were all primary school children in Wolkite town. School children, who met the inclusion criteria from the target, were selected as the participants of this study. An inclusion criterion for this study was all primary school children who had a written consent from the parents or guardians. Children with any evidence of ocular pathology, trauma, previous ocular surgery, long term use of medication and students born to parents who are not from Ethiopia were excluded from the study.

The required sample size was calculated using statistical formula for single population proportion by considering the proportion of defective colour vision in the previous study as $4.2 \%$ [14], with $95 \%$ confidence interval, $2 \%$ margin of error, design effect of 2 and with the assumption of $10 \%$ non response rate. Hence, the final sample size was 850 .

The study participants were selected through multistage sampling technique. Initially, 3 schools out of 12 schools were selected randomly using lottery method. Then, the total sample size was allocated to the selected schools based on probability proportional to size sampling. Finally, a systematic random sampling was employed to select study participants. The student lists was obtained from the school director office and sampling fraction was calculated for each school and it was 5 . The first sample student was selected from 1 to 5 of the student list by lottery method and then the remaining possible sample students were selected every 5 students.

\section{Data collection procedure}

The data were collected by ophthalmic nurses on a face to face interview using structured questionnaires. After collection of socio-demographic characteristics, all the study subjects underwent colour vision evaluation. Colour vision test was done using Ishihara pseudoisochromatic plates (38 plates edition). Before performing the test, the procedure was clearly explained to all subjects. Then, the test was conducted in a room with adequate natural daylight. The plates were held $75 \mathrm{~cm}$ from the study subject and the students were asked to read the numerals which are seen on plates within $3 \mathrm{~s}$. The results were classified based on the instructions described in the attached manual of Ishihara's test plates [15]. Overall, the test was conducted based on the standard recommendation of colour vision test and the details of test process have been described previously [1, 14]. Children having colour vision deficiency underwent detail ocular examination to rule out any ocular pathology. Data quality was assured via training of data collectors, supervision of data collection and the questionnaires were pre tested.

\section{Data analysis}

Data were entered into CSPro version 6.2 statistical software and then exported to SPSS version 23 for analysis. Descriptive statistics was used to present the sociodemographic characteristics of the study participants. Chi square $\left(x^{2}\right)$ test was used to assess statistical significances and p-values of less than 0.05 were considered as statistically significant.

\section{Results}

A total of 844 ( 471 boys and 373 girls) children from 3 randomly selected primary schools were screened with a response rate of $99.3 \%$. The mean ( \pm standard deviation) age of participants was $11.75( \pm 2.5)$ years and the majority of participants were Muslim by religion (Table 1).

After careful screening, it was noted that among the study participants, 35 (4.1\%) students were found to have colour deficient. Out of those students with CVD, 15 $(42.9 \%)$ and $20(57.1 \%)$ were classified as having protan and deutan defects, respectively. Hence, the deutan to protan ratio was 1.3. The prevalence of protan and deutan defects were higher among males as compared to female children (Fig. 1). In the current study, no case of total colour blindness was detected. Moreover, none of the enrolled subjects showed evidence of ocular pathology. Majority, 32 (91.4\%) of the CVD students were unaware of their defect.

In this study, the gender based differences in the prevalence of color vision deficiency was found to be statistically significant $(\mathrm{p}<0.001)$, with a higher prevalence 
Table 1 Socio-demographic characteristics of school children in Wolkite, Southern Ethiopia, $2018(n=844)$

\begin{tabular}{lc}
\hline Variables & $\mathbf{n}(\%)$ \\
\hline Sex & \\
Male & $471(55.8)$ \\
Female & $373(44.2)$ \\
Age (years) & \\
7-12 & $493(58.4)$ \\
13-18 & $351(41.6)$ \\
Religion & \\
Muslim & $387(45.9)$ \\
Orthodox & $364(43.1)$ \\
Protestant & $46(5.5)$ \\
Catholic & $47(5.6)$ \\
School grade & \\
1-4 & $393(46.6)$ \\
5-8 & $451(53.4)$ \\
School & \\
Ras Zesilassie & $355(42.1)$ \\
Aba Firansua Markos & $310(36.7)$ \\
Gasora and Karacha & $179(21.2)$ \\
\hline
\end{tabular}

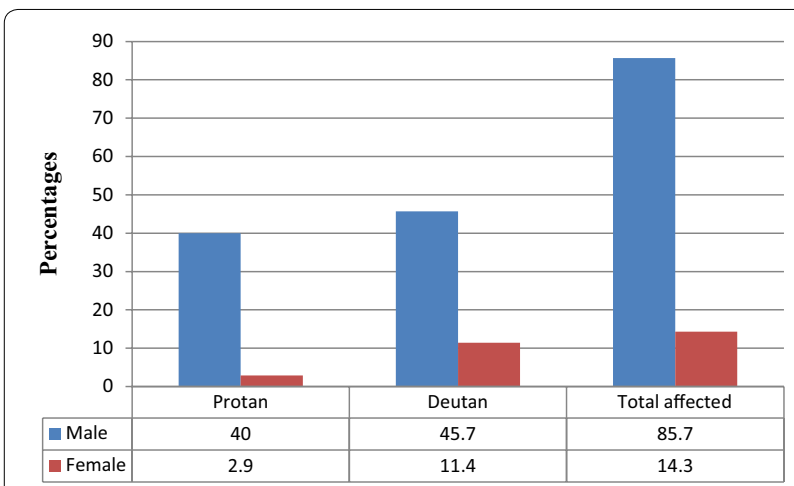

Fig. 1 Distribution of the colour blind subjects according to different types of Color blindness in Wolkite, Southern Ethiopia, $2018(n=35)$

among male $(3.6 \%)$ as compared to female (0.6\%) students. Similarly, there was statistically significant difference in CVD across religion $(\mathrm{p}=0.039)$ in which Muslim children had a higher percentage of CVD than others (Table 2).

\section{Discussion}

This study provides a detailed description of colour vision deficiency in the study area for the first time among school children which provides a basic database on the prevalence of colour blindness in the region. Screening for colour vision in children should be performed for early detection of colour vision deficiency and to reduce the risk of difficulties in lifestyle. In the present study, no other acquired causes of CVD were found. Thus, the possible mechanism of colour blindness might be congenital. A similar finding was also reported by other study [16].

Total colour blindness is the severest forms of congenital colour vision deficiency and was not detected in our study. Hence, colour blind children of this study were partially blind. In the present study, the prevalence of colour vision deficiency was $4.1 \%$, which is nearly similar with the prevalence rates reported in the previous studies $[11,14,17]$. This finding was also comparable with a study done in Thailand, which reported a prevalence rate of $4.2 \%$ [18]. However, the result of this study is higher than the incidence of colour blindness among school children reported as 1.9\% [3] and 2.1\% [19] in Nepal, 2.6\% in Nigeria [20] and 1\% in Bangladesh [16]. A higher prevalence of 5.28\% was reported in India among Manipuri Muslims of both sexes [5]. These variations in the prevalence of CVD from the current study could be due to difference in study population, variation in geographical area, ethnicity and techniques of color vision test.

In the present study the percentage of colour vision deficiency was higher among boys (3.6\%) as compared to girls $(0.6 \%)$. This finding is supported by several studies $[1,13,20,21]$. While other studies $[3,16,19]$ showed that colour blindness was found only among the males. Although, the male: female prevalence ratio is markedly different in different studies, several published literatures showed a higher prevalence of CVD among males compared to females. This is due to $\mathrm{X}$-linked recessive nature of the trait and thus occurs in males [5].

The present study also revealed that most of the colour blind children were deutan. In line with this finding, a high frequency of deutan as compared to protan defects was observed in other studies $[1,14,22]$.

Study done by Bowmaker [23] indicated that the most common form of anomalous colour vision is deuteranomaly. It was suggested that green colour receptor is commonly affected than other cone receptors [16, 23].

Majority of the colour blind children of present study were Muslim by religion, which is supported by other study [16]. Colour blindness is common among the Muslim populations due to frequently practice of consanguinity of marriage among them [16]. Similarly, study done in India [5] and in young Turkish men [24] showed that higher percentages of colour blindness were found in regions with a more consanguineous marriages, which might result in the birth of children with this disorder.

In our study, majority of the study participants did not have a chance of eye examination at all. Students must be made aware of their congenital colour vision deficiency but majority of the CVD students were unaware of their colour vision status. In agreement to our study, study 
Table 2 Distribution of students according to the color vision status among school children in Wolkite, Southern Ethiopia, 2018

\begin{tabular}{|c|c|c|c|c|}
\hline \multirow[t]{2}{*}{ Variables } & \multicolumn{2}{|l|}{ Color vision } & \multirow[t]{2}{*}{$x^{2}$} & \multirow[t]{2}{*}{ p-value } \\
\hline & Normal (\%) & Deficient (\%) & & \\
\hline \multicolumn{5}{|l|}{ Sex } \\
\hline Male & $441(93.6)$ & $30(6.4)$ & 13.24 & $<0.001$ \\
\hline Female & $368(98.7)$ & $5(1.3)$ & & \\
\hline \multicolumn{5}{|l|}{ Age (years) } \\
\hline $7-12$ & $478(97)$ & $15(3)$ & 3.64 & 0.057 \\
\hline $13-18$ & $331(94.3)$ & $20(5.7)$ & & \\
\hline \multicolumn{5}{|l|}{ Religion } \\
\hline Muslim & $365(94.3)$ & $22(5.7)$ & 4.25 & 0.039 \\
\hline Others & $444(97.2)$ & $13(2.8)$ & & \\
\hline \multicolumn{5}{|c|}{ School grade level } \\
\hline $1-4$ & $374(95.2)$ & $19(4.8)$ & 0.87 & 0.350 \\
\hline $5-8$ & $435(96.5)$ & $16(3.5)$ & & \\
\hline \multicolumn{5}{|c|}{ Medical visit } \\
\hline Yes & $148(93.7)$ & $10(6.3)$ & 2.33 & 0.127 \\
\hline No & $661(96.4)$ & $25(3.6)$ & & \\
\hline
\end{tabular}

Numerical data in italic indicates the level of significance $(p<0.05), x^{2}=C h i$ square

done by Mulusew and Yilkal [14] reported that almost all of the study subjects were not aware of their colour vision status. Hence, colour vision screening among school children should be conducted to increase the level of awareness about their colour vision defects.

\section{Conclusion}

The prevalence of colour vision deficiency among school children in the study area was $4.1 \%$. The percentage of colour vision deficiency was found higher among males as compared to females. Children awareness of colour vision status was found to be very low. This indicates the need for establishing continuous visual screening programs among school children. As a recommendation, further community based screening of children for colour vision should be done.

\section{Limitations}

Anomaloscope should be used for detailed analysis of quantitative and qualitative anomalies in colour perception. We couldn't use anomaloscope in our study because the instrument was not available in our set up. The choice of school rather than population based sample was also another limitation of this study. Despite the above limitation this study provides valuable information about the burden of colour vision deficiency among school children in Wolkite town.

\section{Authors' contributions}

GGW: Conception and initiation of the study, develop proposal, implement the study, analyzed it and wrote the draft of the manuscript. TGG: Conceived the study, supervise the data collection, analyzed the data and reviewed the draft of the manuscript. Both authors read and approved the final manuscript.

\section{Acknowledgements}

We would like to thank Wolkite town education office, school directors, teachers, data collectors, supervisors and respondents for their cooperation.

\section{Competing interests}

The authors declare that they have no competing interests.

\section{Availability of data and materials}

The datasets used and/or analyzed during the current study are available from the corresponding author on reasonable request.

\section{Consent for publication}

Not applicable.

\section{Ethics approval and consent to participate}

Ethical clearance was sought from Institutional Review Board of Wolkite University. Then, letter of permission to conduct the study was obtained from the town education office and school directors. Written informed consent was obtained from the parents or guardians after they were fully informed about the purpose of the study. Verbal consent was also obtained from the students who were included in the study. Colour deficient students and their parents received necessary advice about the problem, its prognosis and implication on future career choices.

\section{Funding}

The authors received no financial support for this work and the research was funded by the authors.

\section{Publisher's Note}

Springer Nature remains neutral with regard to jurisdictional claims in published maps and institutional affiliations.

Received: 1 November 2018 Accepted: 21 November 2018

Published online: 28 November 2018

\section{References}

1. Fareed M, Anwar MA, Afzal M. Prevalence and gene frequency of colour vision impairments among children of six populations from North Indian region. Genes Dis. 2015;2(2):211-8.

2. Simunovic MP. Colour vision deficiency. Eye. 2010;24(5):747-55

3. Niroula DR, Saha CG. The incidence of colour blindness among some school children of Pokhara, Western Nepal. Nepal Med Coll J. 2010;12(1):48-50.

4. Dohvoma VA, Mvogo SR, Kagmeni G, Emini NR, Epee E, Mvogo CE. Colour vision deficiency among biomedical students: a cross-sectional study. Clin Ophthalmol. 2018;12:1121-4.

5. Ahsana SH, Hussain R, Fareed M, Afzal M. Prevalence of Red-Green Colour Vision Defects among Muslim Males and Females of Manipur, India. Iranian J Publ Health. 2013;42(1):16-24.

6. Cruz EM, Cerdana HG, Cabrera AM, Garcia CB, Santos-Morabe ET, Nanagas $M$, Lourdes R. Prevalence of colour-vision deficiency among male highschool students. Philipp J Ophthalmol. 2010;35(1):20-4.

7. Swanson WH, Cohen JM. Colour vision. Ophthalmol Clin. 2003;16(2):179-203.

8. Balasundaram R, Reddy SC. Prevalence of colour vision deficiency among medical students and health personnel. Malaysian Fam Phys Off J Acad Fam Phys Malaysia. 2006;1:52-3.

9. Deeb SS, Kohl S. Genetics of colour vision deficiencies. Dev Ophthalmol. 2003;37:170-87. 
10. Birch J. Worldwide prevalence of red-green colour deficiency. J Opt Soc Am A Opt Image Sci Vis. 2012;29(3):313-20.

11. Chakrabarti A, Chakraborti S. Red-green colour vision deficiency and lack of awareness among rural school students in India. Iran J Public Health. 2015;44(7):1018-20.

12. Cole BL. Assessment of inherited colour vision defects in clinical practice. Clin Exp Optom. 2007:90(3):157-75.

13. Rigaudiere F, Leid J, Vienot F, Le Gargasson JF. Neurophysiological basis and clinical tests for assessment of $\mathrm{X}$-linked colour vision deficiencies in school children. J Fr Ophtalmol. 2006;29(1):87-102.

14. Mulusew A, Yilikal A. Prevalence of congenital colour vision defects among school children in five schools of Abeshge District, Central Ethiopia. JOECSA. 2013;17(1):10-4.

15. Ishihara S. Ishihara Instructions [monograph on the Internet]. Japan Academy. https://www.goodlite.com/cw3/Assets/documents/730019\%20lsh ihara\%20Instructions-web.pdf. Accessed 26 Oct 2018.

16. Yasmin A, Janan N, Akhter R. Assessment of colour blindness and erythrocyte G6PD enzyme status among the school children of Dhaka City. J Bangladesh Soc Physiol. 2009;4:64-70.

17. Zein ZA. Gene frequency and type of colour blindness in Ethiopians. Ethiop Med J. 1990;28(2):73-5.
18. Napaporn T, Manassakorn A, Worapong A, Kupat J, Chuwuttayakorn J, Wattananikorn S. Vision Screening in Schoolchildren: two Years Results. J Med Assoc Thai. 2004;87(6):679-84.

19. Shrestha RK, Joshi MR, Shakya S, Ghising R. Colour vision defects in school going children. J Nepal Med Assoc. 2010;50(180):264-2666.

20. Tabansi PN, Anochie IC, Nkanginieme KE, Pedro-Egbe CN. Screening for congenital colour vision deficiency in primary children in Port Harcourt City; teachers knowledge and performance. Nigerian J Med. 2008;17(4):428-32.

21. Xie JZ, Tarczy-Hornoch K, Lin J, Cotter SA, Torres M, Varma R. Multi-Ethnic Pediatric Eye Disease Study Group. Colour vision deficiency in preschool children: the multi-ethnic pediatric eye disease study. Ophthalmology. 2014;121(7):1469-74.

22. Oriowo OM, Alotaibi AZ. Colour vision screening among Saudi Arabian children. Afr Vision Eye Health. 2008;67(2):56-61.

23. Bowmaker JK. Visual pigments and molecular genetics of colour blindness. New Physiol Sci. 1998;13(2):63-9.

24. Citirik M, Acaroglu G, Batman C, Zilelioglu O. Congenital colour blindness in young Turkish men. Ophthalmic Epidemiol. 2005;12(2):133-7.
Ready to submit your research? Choose BMC and benefit from:

- fast, convenient online submission

- thorough peer review by experienced researchers in your field

- rapid publication on acceptance

- support for research data, including large and complex data types

- gold Open Access which fosters wider collaboration and increased citations

- maximum visibility for your research: over 100M website views per year

At BMC, research is always in progress.

Learn more biomedcentral.com/submissions 